\title{
Behavioral Loyalty and Attitudinal Loyalty: Malaysian's Intention on Counterfeit Clothing and Footwear
}

\author{
Annie Ng Cheng San (Corresponding author) \\ Dept. of Commerce and Accountancy, Faculty of Business and Finance, \\ Universiti Tunku Abdul Rahman \\ Jalan University, Bandar Barat, 31900 Kampar, Perak D.R., Malaysia
}

Tel: 605-468 8888 Email: anniencsan@gmail.com

Choy Johnn Yee

Dept. of Marketing, Faculty of Business and Finance,

Universiti Tunku Abdul Rahman

Jalan University, Bandar Barat, 31900 Kampar, Perak D.R., Malaysia

Tel: 605-468 8888 Email: choyjy@utar.edu.my

Received: January 04, 2012 Accepted: February 12, 2012 DOI: 10.5296/jpag.v2i1.1350

\begin{abstract}
Purpose: The research aim to clarify the relationship of brand loyalty: attitudinal, behavioral loyalty with the Malaysian purchase intention on pirated clothing and footwear in order to gain better understanding in developing advance countermeasure.

Design/ Methodology/ Approach: A quantitative research is used to obtain the first hand information. 380 sets of personally- administrated questionnaires were distributed in Malaysia -Penang's Batu Ferringhi Night Market. A variety of statistical analysis techniques were used.
\end{abstract}

Findings: The findings suggested brand loyalty: attitudinal and behavioral have a significant relationship with the purchase intention of counterfeit products. Under the two brand loyalty concepts, the behavioral loyalty had a greater negative association with the consumer intention on counterfeit.

Practical implications: The paper provided in dept knowledge about the consumers motivation on counterfeit products and the information of marketing intelligence strategy-branding which available for the marketers and genuine manufacturers in better 
eradicate the counterfeit activities.

Research Limitations: The paper was primarily focus on the counterfeit clothing and footwear. Although the focus and sample size is adequate and accepted but the generalizability of study may be limited and cannot consider as representative collectively for the whole of Malaysia and other pirated products. Secondly, the quantitative research used had limited the further insight of other unknown variables or factors that do not included.

Keywords: Brand loyalty, Attitudinal loyalty, Behavioral loyalty, Counterfeit, Purchase Intention, Malaysia

\section{Introduction}

"Home for piracy": China, Thailand, India and Malaysia had named as the world's worst violator of intellectual property rights and worst counterfeit offender (Haque, Khatibi and Rahman, 2009). Pirated/ Counterfeit is defined as similar product with poor quality and without authorization of producer (Nordin, 2009; Staake, Thiesse, and Fleisch, 2009). Over the year, counterfeit issue has become worldwide concern which harm towards global economic, social and culture welfare (Haque et. al., 2009). According to International Intellectual Property Institute, these harmful activities shall be responsible for $\$ 200$ billion of unemployment, lost of taxes and revenue. In the Havoscope Global Market Indexes' study, Malaysia has an increase piracy market value of RM 378 million (as cited in Nordin, 2009). Furthermore, in the latest Congressional International Anti-Piracy Caucus, Malaysia has been sited into priority copyright piracy watch list for extra scrutiny to seize the pirated products (“Top 10 Copyright Piracy Nations", 2009).

With all these negative impact, Malaysia government had implemented continuous effect in eradicate this harmful practice. But yet, the demands of pirated are still in the "welcome" trend and can blatantly found at everywhere such as night market and shopping complex. This could be a red alarm to the manufacturer of the genuine product and the government. There is a curious on why the consumers still prefer in purchase the counterfeit good even it bring lots of negative impacts. It is good deal for research to focus on identifying the purchase intention on the counterfeit goods as the demand is the key driver which led to the existence and growth in it.

Looking at the past research, mostly it have been focus on the attitudes towards the counterfeit such as value conscious, integrity, personal gratification, social influences and perceived risks (Ang, Cheng, Lim and Tambyah, 2001; Nordin, 2009). However, less research has been carried on the brand loyalty association on the purchasing intention towards counterfeit products. This research, therefore attempts to fill up the vacuum of past studies by examine on the brand loyalty: attitudinal and behavioral loyalty to test their relationship with the purchase intention of counterfeit product in Malaysia, Penang. In term of brand loyalty variables' operationalization, the past research had a different opinion between the behavioral loyalty and attitudinal loyalty. Therefore, this study had also attempt to provide a better understanding on this two concepts in the research. 
Beyond this, many researches that based on foreign context have been done in response to the consumer's purchase intention towards the pirated software. Therefore, the counterfeit clothing and footwear is focused in this study as it is ranked at the top items pirated just after Cds and Vcds (Mohd Shafie as cited in "Intellectual Property Cases", 2006; Haque et. al., 2009). Through this study, it will able to bring a different view in dealing with the counterfeit market in Malaysia, Penang.

\section{Justification of Study}

The research was conducted in Penang as it is one of the major counterfeit markets in Malaysia (Gatsiounis, 2004). It is currently actively developing to encourage foreign investment such as textile manufacturers (Khor, 2008) and aimed to transform into an international city for the investor choice and destination of choice for tourists ("Penang Chief Minister", 2010). Furthermore, in the latest Economic Transformation Programme, Penang is included and focused as the key wealth creator to assist Malaysia transformation into a high productivity and high income country. One of the main key economic activity is strengthened the Tourism industry in Penang to attract more foreign investments. As pirated products are infringing the intellectual property, the counterfeit issues may become a stumbling block for the project. According to Yeap and Ramayah (2006), the choice of Penang as the main target of study is appropriate as counterfeit products like clothes, software and footwear are highly proliferated especially in the night market Batu Ferringgi and Prangin Mall. Therefore, the finding from the research consequently will provide better understanding towards Penang state government on the actions to get rid of existence of counterfeit products.

In the manufacturer aspect, it is upset case for the owner of genuine product when the counterfeit harvest and share their profit by using their brand name without permissions. As a result to eliminate the harmful practice, several of countermeasures had been implement. But yet, to develop an effective countermeasure, the understanding on the reason behind why people buying the counterfeit version and also what are the associated factor which led the more demand is necessary important. This research therefore, can contribute to the business industry as it is a highly impacted by counterfeit product to stronger their market strategy. It provides hints about the less favorable comparison between original product manufacturers and pirated counterparts which help the practitioners in coping with relentless piracy problems

The general aim of the study is to examine the relationship of brand loyalty with the purchase intention of pirated clothing and footwear. Follow by examine which of the brand loyalty concepts: attitudinal and behavioral loyalty has the greater association with the purchase intention of pirated clothing and footwear. The remained of this paper is organized into several sections begin with the literature review (Section 3). Section 4 is leading to the research question and conceptual framework's development. The description of research design, instruments and methodology is provided in Section 5. Lastly, the discussion of analysis and finding was presented followed by the implication, limitation and recommendation for future research. 


\section{Literature Review}

\subsection{Definition}

Generally, the previous literature categorizes counterfeits into 5 types which include counterfeiting, piracy, imitation brands, a grey area and custom-made copies (Phau and Prendergast, 1998 as cited in Phau, Prendergast, \& Leung, 2000). The terms of counterfeit and pirated are often used interchangeably and both are the reproductions of identical copies of the genuine products without authorization with inferior quality (Wee, Tan and Cheok, 1995; Phau and Teah, 2009; Staake et. al, 2009). Conversely, the counterfeit is dissimilar with the grey market goods and custom made copies. Grey market good is the authorized factories have produced more quantity than requires and sell them as overrun illegally (Gentry, Putrevu and Shultz, 2006). Customs-made copies which are the replicas of branded product. It usually is made by good quality and the only item missing from the original is the brand name. In the research of Phau and Teah (2009) identified two types of consumers which are deceptive counterfeit consumer (victim, unknowingly purchase the pirated products as look similar) and non deceptive counterfeit consumers (purchase the counterfeit version even knew that is illegal).

In this research, the pirate and counterfeit were used interchangeably and non-deceptive consumers were the target respondents in this study.

\subsection{Purchase Intention}

According to the theory of reasoned action (TRA) state that the purchase intention is the surrogate measure of the actual purchase (Ajzen, 1991 as cited in Summers and Belleau, 2006). The best predictor of an individual's behavior is to measure his or her intention to perform behavior (Fishbein and Ajzen, 1975 as cited in Young, DeSarbo \& Morwitz, 1998). Several studies had concluded that there is a significant positive relationship between the purchase intention and purchase behavior (Warshwa, 1980 as cited in Young et al., 1998; Phau, Sequeira and Dix, 2009).

\subsection{Brand Loyalty}

Brand loyalty define as deeply held commitment to re-buy the prefer product/service in future, despite situational influence and marketing effort (Oliver, 1997 as cited Gommans, Krishnan and Scheffold, 2001). The brand loyal consumer will not only tend to repurchase but also refuse to switch even when better offer comes along. According to Oh and Fioritio (2002), there are significant differences between brand loyal and non-brand loyal consumers in the purchase criteria.

The loyal consumer will tend to repeat purchase the preference brand (Rust and Oliver as cited in Paswan, Spear and Ganesh, 2007). This had been supported by Ha, Janda, and Park (2008) which found that there is strong correlation exists between loyalty and the mean number of different stores visit per week. Moreover, the loyal consumers are likely to be less price sensitive, pass on the positive recommendation about the brand and willing to spend more money to their loyal brand (Dowling and Uncles, 1997 as cited in Schoenbachler, 
Gordon and Aurand., 2004). The positive word of mouth that brought by brand loyalty is the mechanism which enable corporation to save the marketing cost (Rundle-Thiele \& Mackay, 2001). Besides that, according to Nia and Zaichkowsky (2000), the loyal consumers will refuse to switch to the counterfeit brand and stay with the original brand as they believed original brand able give them personal satisfaction. Furthermore, past surveys carry on and capture that an individual consumption pattern will symbolize their own social class position. Brand loyal consumer, they will tend to buy the genuine product rather than the pirated version as they perceived the genuine product able to convey their brand status, wealth and also the social class. However, does this apply for Malaysian consumer is an open question. As a result, the following hypothesis was developed:

H1: Brand loyalty is negatively associated with the consumers' purchase intention of counterfeit clothing and footwear.

\subsubsection{Brand Loyalty -Attitudinal and Behavioral Loyalty}

However, in the past researches, the concept of brand loyalty has not been uniquely defined. There were two perspectives in defining the brand loyalty: behavioral and attitudinal loyalty

Some researchers had determined brand loyalty into attitudinal which explain the loyalty stems from the good commitment between the consumer and brand whereas the behavioral which explain brand loyalty of the consumer purchase which result by the purchase habit (Dick and Basu, 1994; Taylor, Goodwin \& Celuch, 2004 as cited in Gil, Andres and Salinas, 2007).

The repeat purchase (behavioral loyalty) may not reflect the true loyalty as it might buy through bribes such as price discount and coupons (Dick and Basu, 1994; Light, 1997 as cited in Schoenbachler et al., 2004). Thus, it is not a sufficient concept of brand loyalty as there is difference between brand loyalty and repeat buying behavior. Therefore, they had stressed upon the need to extend the concept of brand loyalty to include the attitudinal and behavioral influences and both concepts are required to define brand loyalty. Brand loyalty could be better understood by extending the behavioral definition so as to encompass attitudes (along with behavior) to measure loyalty (Baloglu, 2002; Ha et. al., 2008). However, according to Sharp, Sharp and Wright (2002), the attitudinal loyalty is not relevant in determining the brand loyalty and the arguments on the true definition of loyalty are wasting time. In addition, behavioral loyalty is important as it focuses on the value of customer towards the brand (Schultz and Bailey, 2000). The research suggested that focusing only on the behavioral loyalty is not sufficient enough to capture the purchase intention. The attitudinal loyalty is relevant (Baloglu, 2002; Ha et. al., 2008). Therefore the attitude and behavioral is the requirement for the true loyalty to occur.

Thus, the following hypothesis was employed:

H1a: The behavioral loyalty is negatively related towards consumers' purchase intention of counterfeit cloth and footwear.

H1b: The attitudinal loyalty is negatively related towards consumers' purchase intention of 
counterfeit cloth and footwear.

\section{Theoretical Framework and Research Question}

Base on the above literature review, the research framework was developing to examine the relationship between brand loyalties: behavioral and attitudinal loyalty with the purchase intention of counterfeit clothing and footwear. The theoretical framework as illustrated in Figure 1:

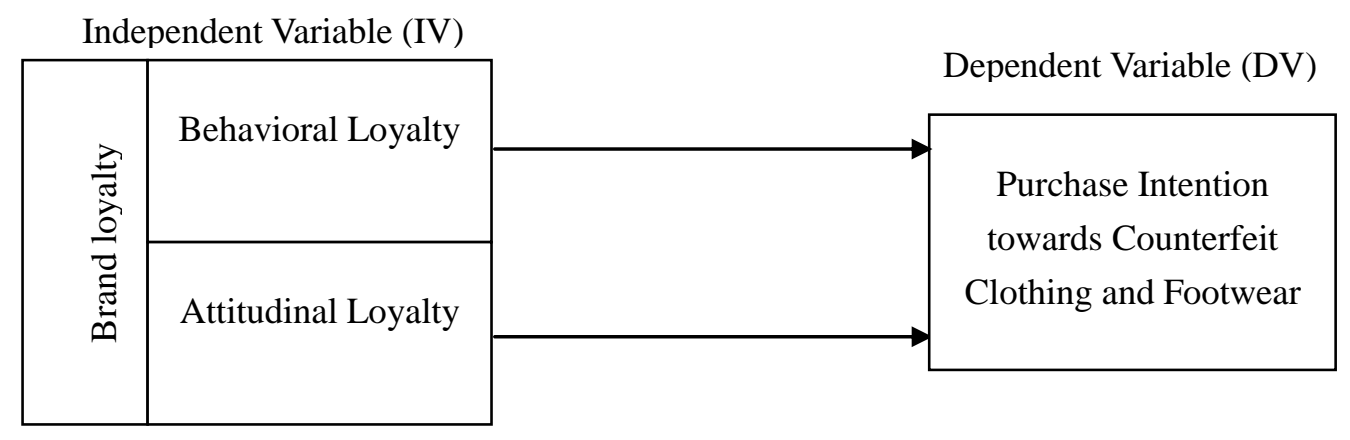

Figure 1: Proposed theoretical framework

The two research questions of the paper can be expressed as:

$R Q 1$. Does the brand loyalty have relationship with the purchase intention of counterfeit clothing and footwear?

$R Q 2$. If so, between the two concepts in defining the brand loyalty, behavioral loyalty and attitudinal loyalty, which one has the greater association with the purchase intention of counterfeit clothing and footwear?

\section{Methodology}

The target population of this study was based on Malaysia, Penang population from the age of fifteen and above which is 1062950 ("Population and Development", n.d.). A quantitative research had used to test the hypothesis through the questionnaires. 380 sets of personally administrated questionnaires had been distributed at Batu Ferringhi Night Market in Penang from evening to night due to high counterfeit product can be found, ease and simplicity. According to Sekaran (2003), the advantage of personally administered questionnaire is complete response can be collected and any doubts on the questionnaires can be clarified immediately. Ages of 15 and above were investigated as below age of 15 is considered as young population (Ong \& Baharum, 2001). Furthermore, Hair, Anderson, Tatham and Black (2010) suggested that parameter ratio of 20:1 is the adequate sample size to achieve meaningful estimate. For this paper, parameter ratio of 127:1 used which is exceed suggest ratio, therefore the sample size in this paper is adequate and accepted. In this research, we used quota sampling and race will be our determination for choosing our quota sample (Malays 41\%, Chinese 42\%, Indians 10\% and others 7\%) (Department of Statistics, Malaysia as cited in SERI, 2007). The 5 point Likert scale from 0: strongly disagree to 4: strongly agree was used in the questionnaire. To avoid the tendency of respondents in mechanically 


\section{Macrothink \\ Journal of Public Administration and Governance \\ ISSN 2161-7104 \\ 2012, Vol. 2, No. 1}

answer the questions, negatively worded questions was adopted.

\section{Analyses of Data}

Factor analysis was primarily taken for the studied variable. Reliability coefficient and intercorrelations were also computed to understand the variability and interdependence of the subscale derived from the factor analysis. The data were analyzed using the correlation and multiple regressions. The Multiple regression analysis was employed to test the hypotheses.

\subsection{Findings}

\subsubsection{Profile of respondents}

A number of 380 respondents were approached and fully completed questionnaires were obtained, with a respond rate of $100 \%$. From the collected questionnaires, there were no dropped or missing for our research. The reason behind is that we are using personal administrated approach to collect our data.

Table 1 showed the demographic profile of respondents involved in the study based on frequency and percentage. The demographic variables used in the study were (a) gender, (b) age (c) race (d) income level, and (e) education level. The sample was divided into 2 groups, male $(45 \%)$ and female (55\%). People from age groups of 15 until 65 and above were represented. Nevertheless, majority of the respondents aged between 25 to 34 years old (28.9\%). Follow by the age group of 15 to 24 (28.7\%). Only a small fraction of them was senior citizens (1\%). For race, we are based on our quota sampling from our population which has been stated earlier. For Chinese, the percentage is $42 \%$ which has 160 respondents. Second is followed by Malay where the percentage is $41 \%$ which has 156 respondents. Next is Indian where there are a percentage of $10 \%$ and 38 respondents. The last is the respondents from other race which has a percentage of $7 \%$ and 27 respondents. Regarding to the monthly household income level, most of the respondents, 164 numbers of respondents in the study earned between RM2000 to RM 3499 per month. The survey shows that the group of RM2000 and below has a respondents of 114 and 102 respondents from the group of income is RM 3500 and above. For education level, most of our respondents were from secondary school which is 154 respondents and least is from group of primary school which is 22 respondents. 


\begin{tabular}{|c|c|c|}
\hline \multicolumn{3}{|c|}{ Table 1: Respondents' Demographic Profiles } \\
\hline \multicolumn{3}{|c|}{ Sample Characteristics $(\mathrm{n}=380)$} \\
\hline Characteristics & Frequency & Percentage $(\%)$ \\
\hline \multicolumn{3}{|l|}{ Gender } \\
\hline - Male & 170 & 44.7 \\
\hline - Female & 210 & 55.3 \\
\hline \multicolumn{3}{|l|}{ Age } \\
\hline-15 to 24 & 109 & 28.7 \\
\hline-25 to 34 & 110 & 28.9 \\
\hline-35 to 44 & 88 & 23.2 \\
\hline-45 to 54 & 35 & 9.2 \\
\hline-55 to 64 & 33 & 8.7 \\
\hline-65 and above & 5 & 1.3 \\
\hline \multicolumn{3}{|l|}{ Race } \\
\hline - Malay & 156 & 41.1 \\
\hline - Chinese & 160 & 42.1 \\
\hline - Indian & 38 & 10.0 \\
\hline - Others & 26 & 6.8 \\
\hline \multicolumn{3}{|l|}{ Income level } \\
\hline - Below RM1200 & 114 & 30.0 \\
\hline - RM1200-RM3499 & 164 & 43.2 \\
\hline - RM3500 and above & 102 & 26.8 \\
\hline \multicolumn{3}{|l|}{ Level of education completed } \\
\hline - Primary & 22 & 5.8 \\
\hline - Secondary & 154 & 40.5 \\
\hline - College/Pre-University & 126 & 33.2 \\
\hline - University & 78 & 20.5 \\
\hline Total & 380 & 100 \\
\hline
\end{tabular}

\subsubsection{Factor Analysis}

A factor analysis was conducted to evaluate the construct validity. Although the survey used is according the suggestion of past researches and it has not been applied in the counterfeit field in Malaysia. Therefore, a varimax rotated principle component factor analysis was conducted on the dependent variable: purchase intention and independent variable: brand loyalty: attitudinal loyalty and behavioral loyalty which comprising 12 items. According to Hair et al. (2010), only loading of 0.5 or greater on the factor and 0.35 or lower on the other factor was considered. The result of factor analysis for dependent and independent variable was summarized in Table 2. The result for factor analysis extracted the independent variable with eigenvalues greater than one and the variance was $63.819 \%, 66.105 \%$ and $56.333 \%$ respectively. Furthermore the KMO measures of all the independent variables' sampling adequacy was more than 0.60 (from range 0.688 to 0.763 ) while the Barlette's test was 
significant (less than 0.01). For the factor loading analysis for the dependent variable was conducted in order to view the dimensionality of purchase intention (dependent variable). A single factor solution emerged with the eigenvalue of 1.00 and a total variance was $63.819 \%$. KMO sampling adequacy measurement was 0.826 (greater than 0.6) while the Barlett's test was significant (less than 0.01).

\begin{tabular}{|c|c|c|c|c|c|c|c|}
\hline \multicolumn{8}{|c|}{ Table 2: Factor Analysis } \\
\hline & Variable & & Item & $\begin{array}{c}\text { Factor } \\
\text { Loading }\end{array}$ & KMO & $\begin{array}{c}\text { Barlett's } \\
\text { test }\end{array}$ & Variance $\%$ \\
\hline DV & $\begin{array}{l}\text { Purchase } \\
\text { Intention }\end{array}$ & & $\begin{array}{l}\text { PI } 6 \\
\text { PI } 7 \\
\text { PI } 8 \\
\text { PI } 9 \\
\text { PI } 10\end{array}$ & $\begin{array}{l}0.665 \\
0.657 \\
0.879 \\
0.871 \\
0.887\end{array}$ & 0.826 & 0.000 & 63.819 \\
\hline IV & $\begin{array}{l}\text { Brand } \\
\text { loyalty }\end{array}$ & $\begin{array}{l}\text { Behavioral } \\
\text { Attitudinal }\end{array}$ & $\begin{array}{l}\text { BL } 11 \\
\text { BL } 13 \\
\text { BL } 15 \\
\text { BL } 12 \\
\text { BL } 14 \\
\text { BL } 16 \\
\text { BL } 17\end{array}$ & $\begin{array}{l}0.801 \\
0.828 \\
0.810 \\
0.778 \\
0.767 \\
0.694 \\
0.760 \\
\end{array}$ & 0.763 & 0.000 & 56.333 \\
\hline
\end{tabular}

\subsubsection{Internal Reliability Analysis}

According to Hair et al., (2010), reliability test needed to conduct in order to determine the stability and consistency of the construct measurement. To access the interim consistency reliability of all variables, Cronbach's Alpha was used. It is the most widely and popular reliability coefficient test used to examine the reliability of multi-pointed scaled items (Sekaran, 2003). According to Sekaran (2003), it is suggested that the reliability coefficient of variable less than 0.60 is consider to be poor, those exceed 0.70 range is acceptable. The reliability test of dependent and independent variable has summarized in Table 3, which all the variables from range of $0.741,0.744$ and 0.848 which exceed the acceptance level of 0.7 suggested. Therefore, all variables were proved to be stable and consistent.

\begin{tabular}{|l|l|c|c|}
\hline \multicolumn{4}{|c|}{ Table 3: Reliability coefficient Cronbach's Alpha } \\
\hline Construct & & Alpha Coefficient & Number of Items \\
\hline Purchase Intention & & 0.848 & 5 \\
\hline Brand Loyalty & Behavioural & 0.744 & 3 \\
\cline { 2 - 4 } & Attitudinal & 0.741 & 4 \\
\hline
\end{tabular}




\subsubsection{Correlation analysis: relationship between variables}

The correlation coefficient between behavioral loyalty, attitudinal loyalty (the independent variables) and the dependent variable: purchase intention is tabulated in Table 4.

\begin{tabular}{|l|l|c|c|c|c|}
\hline \multicolumn{6}{|c|}{ Table 4: Correlation Coefficient Independent and Dependent Variables } \\
\hline \multirow{2}{*}{} & & $\begin{array}{c}\text { Purchase } \\
\text { intention }\end{array}$ & $\begin{array}{c}\text { Behavioral } \\
\text { Loyalty }\end{array}$ & $\begin{array}{c}\text { Attitudinal } \\
\text { Loyalty }\end{array}$ & $\begin{array}{c}\text { Price } \\
\text { Differential }\end{array}$ \\
\hline $\begin{array}{l}\text { Purchase } \\
\text { Intention }\end{array}$ & Pearson Correlation & 1 & & & \\
\cline { 2 - 6 } & Sig. (2-tailed) & & & & \\
\hline $\begin{array}{l}\text { Behavioral } \\
\text { Loyalty }\end{array}$ & Pearson Correlation & $-0.415^{* *}$ & 1 & & \\
\cline { 2 - 7 } & Sig. (2-tailed) & 0.000 &. & & \\
\hline $\begin{array}{l}\text { Attitudinal } \\
\text { Loyalty }\end{array}$ & Pearson Correlation & $-0.400^{* *}$ & $0.787^{* *}$ & 1 & \\
\cline { 2 - 7 } & Sig. (2-tailed) & 0.000 & 0.000 & & \\
\hline
\end{tabular}

\section{**Correlation is significance at the level 0.01 level (2-tailed)}

As revealed in Table 4, the correlation coefficients for the variable under investigation were relatively high ranging from -0.415 to 0.787 . The both level of behavioral loyalty have a negative correlation with the purchase intention of private clothes and footwear (behavioral loyalty, $\mathrm{r}=-0.415, \mathrm{p}<0.01)$. Follow by the attitudinal loyalty $(\mathrm{r}=-0.400, \mathrm{p}<0.01)$. In general term of the brand loyalty variables, it showed that there is a significant negative association $(\mathrm{p}<0.01)$ with the purchase intention of counterfeit clothing and footwear. According to Hair et al. (2010), multi-collinearity occurs if the r-value between each pair of IV in Pearson's correlation exceeds 0.90 . The highest coefficient of correlation in this research is 0.787 which is below the cutoff point of 0.90 for the collinearity problem. Therefore, it indicated that the data was not affected by the multi-collinearity problem. The correlation was also further evidence of validity and reliability of the measurement scales used in this study. The result from Table 4 showed that the behavioral loyalty has the greater association to the purchase intention of counterfeit clothing and footwear.

\subsubsection{Multiple regression analysis}

Multiple regression analysis was conducted to test the hypothesis. According to Hair et. al (2010), multiple regression analysis is applied to analyze the relationship between one dependent variable with the several independent variables.. The summary of regression analysis had showed in Table 5. 


\begin{tabular}{|c|c|c|c|c|c|c|c|}
\hline \multicolumn{8}{|c|}{ Table 5: Multiple Regression Analysis } \\
\hline & \multicolumn{2}{|c|}{$\begin{array}{c}\text { Un standardized } \\
\text { Coefficient }\end{array}$} & \multirow[b]{2}{*}{$\mathrm{t}$} & \multirow[b]{2}{*}{$\begin{array}{l}\text { Sig } \\
\text { level }\end{array}$} & \multirow[b]{2}{*}{ Results } & \multicolumn{2}{|c|}{$\begin{array}{c}\text { Collinearity } \\
\text { Statistics }\end{array}$} \\
\hline $\begin{array}{c}\text { Independent } \\
\text { variable }\end{array}$ & B & $\begin{array}{c}\text { Standard } \\
\text { Error }\end{array}$ & & & & $\begin{array}{c}\text { Toleranc } \\
\mathrm{e}\end{array}$ & VIF \\
\hline (Constant) & 3.367 & 0.098 & 34.430 & 0.000 & Accept & & \\
\hline $\begin{array}{l}\text { Behavioral } \\
\text { Loyalty }\end{array}$ & -0.266 & 0.076 & -3.509 & 0.001 & Accept & 0.380 & 2.633 \\
\hline $\begin{array}{l}\text { Attitudinal } \\
\text { Loyalty }\end{array}$ & -0.230 & 0.89 & -2.573 & 0.010 & Accept & 0.380 & 2.633 \\
\hline $\mathrm{R}^{2}$ & 0.205 & & & & & & \\
\hline Adjusted $\mathrm{R}^{2}$ & 0.199 & & & & & & \\
\hline F-value & 43.634 & & & & & & \\
\hline $\begin{array}{l}\text { F-value sig. } \\
\text { level }\end{array}$ & 0.000 & & & & & & \\
\hline $\begin{array}{l}\text { Durbin Watson } \\
\text { test }\end{array}$ & 1.665 & & & & & & \\
\hline
\end{tabular}

According to Ott and Longnecker (2001), Durbin-Watson (DW) statistic tests the residuals to determine if there is any significant correlation based on the order in which they occur in the data file. From the result in Table 5, the Durbin Watson of 1.665 was fall between the ranges of $1.5 \leq \mathrm{DW} \leq 2.5$, therefore indicate that no autocorrelation problem in the data. Furthermore, the variance inflation factor (VIF) and Tolerance was used to analysis the multi-collinearity among the independent variable (Ott and Longnecker, 2001). From the result, the VIF is lesser than 10 (range $=2.633)$ and tolerance are all greater than $0.1($ range $=0.380)$ which suggest by Ott and Longnecker (2001). As a result, multi-collinearity problem does not exist. The residual scatter plots was conducted and indicate that the normality (fall within the range of \pm 3 ) and linearity of relationship between dependent variable and independent variables. Therefore, the assumption of multiple regression models in this study had meet to ensure the validity of the significance test (Ooi, Safa and Arumugam, 2006). There is a statistically significant relationship between purchase intention of counterfeit clothing and footwear with the behavioral loyalty and attitudinal loyalty. For the magnitude effect of this study, Cohen rules for effect size are used. According to Cohen (1998), $\mathrm{R}^{2}$ between the range of 1.0 to 5.9 percent is consider as small size, follow by the moderate range between 5.9 to 13.8 and range which is above 13.8 percent is consider large (as cited in Jitpaiboon and Rao, 2007). In the result of regression analysis, the $\mathrm{R}^{2}$ is 0.205 (consider large effect), means $20.5 \%$ of the purchase intention can be explained by the independent variable. The F-value is 43.634 with the significant level at $1 \%$ (p-value $=0.000$ ). Thus, the fitness of the model is confirmed.

\section{Discussion}

The overall objective for the study is to investigate the relationship of brand loyalty towards the purchase intention of counterfeit clothing and footwear. For the hypothesis of H1, the brand loyalty nature was found to be significantly negative correlated with the consumers' 
purchase intention of counterfeit. The both nature of brand loyalty: attitudinal and behavioral loyalty had found consist a significant (less than 0.01) and negative relationship with the consumer intention to purchase counterfeit clothing and footwear.

For hypothesis H1a:

The behavioral loyalty is negatively related towards consumers' purchase intention of counterfeit cloth and footwear.

In the result showed in Table 2, the significant value for behavioral loyalty is 0.001 with a beta value of -0.266 . Therefore, H1a is supported and indicate that the behavioral loyalty has significant negative relationship toward the consumer purchase intention of counterfeit clothing and footwear. When the consumer has strong behavioral loyalty on the genuine product, they will have low intention to purchase the counterfeit version clothing and footwear.

For hypothesis H1b:

The attitudinal loyalty is negatively related towards consumers' purchase intention of counterfeit cloth and footwear.

The analysis in Table 2 , showed that the attitudinal loyalty have a beta value of -0.230 with a significant level of 0.010 ( $<$ than the 0.05 ). Therefore, H1b is also supported. The attitudinal loyalty is negatively related towards the purchase intention of counterfeit version. When consumer has greater and strong attitudinal loyalty towards the origin clothing and footwear, they will less intention to purchase counterfeit version.

\section{Conclusion and Implications}

The findings of this study are expected to contribute to research and practice or managerial contribution. Counterfeit issues have become global, occurring not only in less developed countries, but also in many well-developed countries. Malaysia is not in exception of this issue.

To respond the first and second research question $R Q 1$ : does the brand loyalty has a significant relationship with the purchase intention of counterfeit clothing and footwear, the finding provided the empirical evidence that both variables have a significant relationship with the consumer purchase intention of counterfeit version. For brand loyalty variable, the findings indicate there is a significant negatively correlated with the purchase intention of counterfeit clothing and footwear.

For research question $R Q 2$ : attitudinal and behavioral loyalty, which has the greater association with the consumer purchase intention over the counterfeit clothing and footwear. The finding under the multiple regression and Pearson correlation analysis convinced that both loyalties nature consist a significant and negative relationship with the consumer intention to purchase the counterfeit product. In the multiple regression analysis, the beta value of the behavioral loyalty (-0.266) showed that it has the greater negative association with consumer purchase intention of counterfeit compare with the attitudinal loyalty $(-0.230)$. 


\section{Macrothink}

The behavioral loyalty is perceived as the dominant of brand loyalty concept. This is supported by the Sharp et. al (2002), which stated that the behavioral loyalty is the true and significant loyalty in the brand loyalty concept. However, from the finding of this study, it also proved that both loyalty concepts have a significant and negative relationship with the purchase intention of counterfeit clothing and footwear.

\subsection{Managerial Implication}

With the finding from this study proven that the assumptions of brand loyalty made in the earlier chapter can be overcoming the pirated issues has been proved. The brand loyalty consists of negative significant relationship with the consumer purchase intention of counterfeit. The stronger brand loyalties able to implement, there will be decrease on the intention for the consumer to purchase the counterfeit product. In the efforts to eliminating the pirated, this study shown convincingly to the various parties such as manufactures, law enforcers, and consumers for taking into the account the brand loyalty as a useful tool. Meanwhile, between the behavioural and attitudinal loyalty, the result taken has shown the behavioural loyalty brings greater association in the purchase intention. This is worth to take notes for the future uses. However, we cannot ignore the significant of the attitudinal loyalty in defining the brand loyalty. As suggested by previous studies, both of the concept is required in determine the true brand loyalty.

This research able to contributed to the body of knowledge, management, and Penang state government by providing a conceptual model. By focusing on the two factors on their significant relationship with the purchase intention of counterfeit clothing and footwear, managements of the brands can better control the pirated market and reduce its impacts. Beyond this, the limited awareness on the intellectual property right among the consumers had cause the increase trend on demand. Therefore, effective education affair is also one of the major leverage to confine the unlawful pirated activities. However, with the current counterfeit growth issue, the countermeasure such as high tech labelling, awareness programme seem like not sufficient enough. Knowledge about the current counterfeit illicit activities such as the quality, pricing and promotion technique of the counterfeit must be developed. Therefore, this study provides the understanding of the "attractive" reason of counterfeit and the association with brand loyalty: attitudinal and behavioural loyalty, the manufacturer can leverage and reduce the unlawful opportunistic act.

\subsection{Theoretical Implication}

From the theoretical perspective, this study had extended past research's literature to focus on counterfeit clothing and footwear. This will lead to better contribution of literature to fill up the gaps of the past study. Furthermore, this problematic issue shall not only focus on the manufacturer but also the demand of consumer. Therefore, for enhancing a better knowledge on effective countermeasure, the understanding on consumers' intention on counterfeit also important to note. As a result, the paper had contributed in-dept understanding of the consumer purchase intention and the association factors which related to the counterfeit clothing and footwear. 


\section{Research Limitations}

In our study, we only focus on counterfeit clothing and footwear. Other categories and deceptive fakes may elicit different responses from the research. This means that other pirated product such as watches or electronic products or software might have the different finding.

Secondly, although the sample size in this study is adequate and acceptable, the generalizability of the research on counterfeit product may be limited. The finding might not be representation collectively the whole of Malaysia. Therefore, it is advisable for the future research should go through cross-countries in order to have better generalizability for the study.

Additions, the surveys were conducted by the use of quantitative research, personally administrated survey method. Therefore, the further insight of other unknown variables or association factors might be limited. It is difficult to determine through a survey or questionnaire on the consumer purchase intention towards the counterfeit product are pervasive or apparent. Due to only limit variables or construct had been including on this study. Therefore, there is a risk that a significant factor might not be including in the framework.

\section{Future Research Direction}

In order to capture diversity of research, future researchers are suggested to extend the products with varying degrees on involvement and what is not uncovered in this study as reflect in the discussion and categories. The future research could focus on different of product categories such as electronic product, watches, alcohol drinks and other to yield more proper findings on the purchase intention on different categories. It is advisable for the examination should go through cross-countries in order to have better generalizability for the study. Additions, future research also recommended investigating on other influences such as quality, gender, ethnic, or consumer behavior towards purchase intention of counterfeit goods. Different ethnic groups will have different purchase intention towards the pirated product (Cui and Choudhuri, 2002). Thus, it is a new direction for researchers to investigate on how these different ethnic groups or the cultural difference could affect purchase intention on counterfeit products. Lastly, the further exploration using qualitative method and longitudinal study is highly recommended as it provide better insight on the extra and unknown association factors on the intention of counterfeit products.

\section{Acknowledgement}

We hereby appreciate $\mathrm{Ng}$ Sue Yee, $\mathrm{Ng}$ Huey Tyng and Dennis Lo Kin Haw for the assistance of data collection. We are grateful to the target respondents in Penang who provided the valuable information and feedback towards this study. 


\section{References}

Ang, S. H., Cheng, P. S., Lim, E. A. C., \& Tambyah, S. K. (2001), "Spot the difference: consumer responses towards counterfeits", Journal of Consumer Marketing, 18, 219-235.

Baloglu, S. (2002), "Dimensions of customer loyalty: separating friends from well wishers", Cornel Hotel and Restaurant Administration Quarterly, 43, 47-59.

Cui, G., and Choudhury, P. (2002). Marketplace diversity and cost-effective marketing strategies. Journal of Consumer Marketing, 19(1), 54-73.

Gatsiounis, L. (2004), "Southeast Asia: Malaysia's CD pirates make a comeback", available at http://www.atimes.com//atimes/Southeast_Asia/FC18Ae01.html (accessed 1 April 2008).

Gentry, J. W., Putrevu, S., Shultz, C. J. (2006), "The effects of counterfeiting on consumer research", Journal of Consumer Behavior, 5(3), 245- 256.

Gil, R. B., Andres, E. F., \& Salinas, E. M. (2007), "Family as a source of consumer-based brand equity", Journal of Product \& Brand Management, $\quad$ Vol.16, No. 3, pp. 188-199.

Gommans, M., Krishnan, K. S., \& Scheffold, K. B. (2001), "From brand loyalty to e-loyalty: A conceptual framework", Journal of Economic and Social Research, 2(1), 43-58.

Ha, H.Y., Janda, S., and Park, S.K. (2008), "Role of satisfaction in an integrative model of brand loyalty- Evidence from China and South Korea", International Marketing Review, 26(2), 198-220.

Hair, J. F. Jr., Black, W.C., Babin, B. J. and Anderson, R.E. (2010). Multivariate data analysis: A global perspective. ( $7^{\text {th }}$ ed.). New Jersey: Pearson Education Inc.

Haque, A., Khatibi, A., and Rahman, S. (2009), "Factor influencing buying behavior of piracy products and its impact to Malaysian market", International Review of Business Research, 5(2), 383- 401.

Jitpaiboon, T. and Rao, S. S. (2007), "A meta analysis of quality measures in manufacturing system”, International Journal of Quality and Reliability Management, 24(1), 78-102.

Khor, N. (2008), "Watching Penang 'grow", available at http://www.malaysiakini.com/opinions/79059 (accessed 10 April 2008).

Mohd, S. (2006), "Intellectual Property Cases Should Be Speeded Up", Bernama.com., July 18, available at http://www.bernama.com.my/bernama/v3/news.php?id=208733 (accessed 12 December 2009).

Nia, A. \& Zaichkowsky, J. L. (2000), "Do counterfeits devalue the ownership of luxury brands?", Journal of Product \& Brand Management, 9(7), 485-497.

Nordin, N. (2009), "A study on consumers' attitude towards counterfeit products in Malaysia”. Unpublished master's thesis, University of Malaya.

Oh, J., Fiorito, and S. S. (2002), “Korean women's clothing brand loyalty”, Journal of 
Fashion Marketing and Management, 6(3), 206-222.

Ong, A. and Baharom, B. (2001), "Economic Briefing to the Penang State Government", available at http://www.seri.com.my/oldsite/EconBrief/EconBrief2001-10.PDF (accessed 8 April 2008).

Ooi, K. B., Safa, M. S. and Arumugam, V. (2006), "TQM practice and affective commitment: a case of Malaysian semiconductor packaging organizations", International Journal of Management and Entrepreneurship, 2(1), 37-55.

Ott, R. L., and Longnecker, M. (2001), An introduction to statistical methods and data analysis, Thomson Learning Inc, Duxbury,

Paswan, A. K., Spear, N., and Ganesh, G. (2007), "The effects of obtaining one's preferred service brand on consumer satisfaction and brand loyalty", Journal of Service Marketing, 21(2), 75-87.

Phau, I., and Teah, M. (2009), "Devil wears(counterfeit) Prada: a study of antecedents and outcomes of attitudes towards counterfeits of luxury brands, Journal of Consumer Marketing, 26(1), 15-27.

Phau, I., Prendergast, G. and Leung, H. C. (2000), "Profiling brand-piracy-prone consumers: An Exploratory study in Hong Kong' clothing industry", Journal of Fashion Marketing and Management, 5(1), 45-55.

Phau, I., Sequeira, M., and Dix, S. (2009), "To buy or not to buy a "counterfeit" Ralph Lauren polo shirt- the role of lawfulness and legality toward purchasing counterfeits", AsiaPacific Journal of Business Administration, 1(1), 68-80.

"Population and Development Indicators for Asia and Pacific", 2007, Available at http://www.unescap.org/esid/psis/population/database/data_sheet/2007/DataSheet2007.pdf (accessed 7 April 2008).

Rundle-Thiele, S., \& Mackay, M. M. (2001), "Accessing the performance of brand loyalty measures”, Journal of Services Marketing, 15(7), 529-546.

Schoenbachler, D. D., Gordon, G. L., \& Aurand, T. W. (2004), "Building brand loyalty through individual stock ownership”, Journal of Product \& Brand Management, 13(7), 488-497.

Schultz, D. E., and Bailey, S. (2000), "Developing a total customer marketing programme", Journal of Targeting, Measurement and Analysis for Marketing, 8(4), 303-313.

Sekaran, U. (2003), Research methods for business: A skill building approach (4th edition), John Wiley \& Son, Inc., New York.

SERI Socio-Economic \& Environmental Research Institute-Penang Statistics Quarter 4, 2007, available http://www2.seri.com.my/Penang\%20Statistics/2007/Q4\%20Jan\%20-\%20December\%20200 
7-1.pdf (accessed 7 April 2008).

Sharp, A., Sharp, B., and Wright, M. (2002), "Questioning the value of the "True" brand loyalty distinction", International Journal of Research in Marketing, 19(1), 81-90.

Staake, T., Thiesse, F., and Fleishch, E. (2009), "Commentary- The emergence of counterfeit trade: a literature review”, European Journal of Marketing, 43(3/4), 320- 349.

Summers, T. A., and Belleau, B. D. (2006), "Predicting purchase intention of a controversial luxury apparel product”, Journal of Fashion Marketing and Management, 10(4), 405-419.

"Top 10 Copyright Piracy Nations", (2009), available at http://www.blogtactic.com/2009/05/top-10-copyright-piracy-nations.html（accessed 1 December 2009).

Wee, C. H., Tan, S. J., \& Cheok, K. H. (1995), "Non-price determinants of intention to purchase counterfeit goods: An exploratory study", International Marketing Review, 12(6), 19-46.

Yeah, J. A. L., and Ramayah, T. (2006). Unraveling perceptions on counterfeit goods: insights from the Malaysian mindset. Delhi Business Review, 7(1), 47-58.

Young, M. R., DeSarbo, W. S., \& Morwitz, V., G. (1998), "The stochastic modeling of purchase intentions and behavior”. Management Science, 44(2), 188-202.

\section{Copyright Disclaimer}

Copyright reserved by the author(s).

This article is an open-access article distributed under the terms and conditions of the Creative Commons Attribution license (http://creativecommons.org/licenses/by/3.0/). 